\title{
Boletín de la Sociedad Geológica Mexicana
}

VOLUMEN 67, NÚM. 3, 2015, P. 509-516

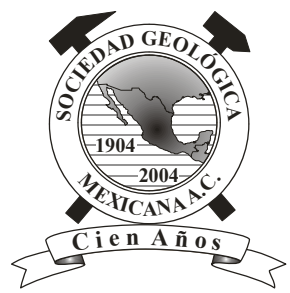

\section{pH dependence of Glyphosate adsorption on soil horizons}

\author{
Hector R. Tévez ${ }^{1}$, Maria dos Santos Afonso 2,** \\ ${ }^{1}$ Facultad de Ciencias Forestales, Universidad Nacional de Santiago del Estero. Avenida Belgrano Sur 1912. 4200 Santiago del \\ Estero, Argentina. \\ ${ }^{2}$ INQUIMAE, Facultad de Ciencias Exactas y Naturales- Universidad de Buenos Aires. Ciudad Universitaria, Pabellón II, 3er Piso, \\ Ciudad Autónoma de Buenos Aires, C1428EHA, Argentina. \\ *dosantos@qi.fcen.uba.ar
}

\begin{abstract}
Pesticides bring many problems to the environment and to human health. The first rationale for their use is increased food production. Glyphosate N-(phosphonomethyl)glycine (PMG) is a non-selective, post emergent, and broad spectrum herbicide, very well known for its extensive application in agriculture worldwide. PMG adsorption experiments were carried out in three horizons of a Typic Haplustoll soil from the Province of Santiago del Estero, Argentina.

Adsorption isotherms were fitted using Freundlich and Langmuir models. The affinity constants $\left(\mathrm{K}_{\mathrm{F}}\right.$ and $\left.\mathrm{K}_{\mathrm{L}}\right)$, the adsorption intensity $(1 / \mathrm{n})$ and the maximum surface coverage $\left(\Gamma_{\max }\right)$ were obtained. The results show the dependence of the parameters $\mathrm{K}_{\mathrm{L}}$ and $\Gamma_{\max }$ with $\mathrm{pH}$ and also with the different horizons and particle size.
\end{abstract}

Keywords: Glyphosate, Adsorption isotherm, horizon, profile.

\section{Resumen}

Los pesticidas producen muchos problemas al ambiente y a la salud humana. La primera racionalización que considera el aumento en su aplicación es incrementar la producción de alimentos. El glifosato, $N$-fosfonometilglicina (PMG) es un herbicida no selectivo, post-emergente y de amplio espectro que es de uso extensivo en agricultura a nivel mundial. La adsorción de PMG fue llevada a cabo en tres horizontes de un suelo de la Provincia de Santiago del Estero, Argentina, clasificado como Haplustol Típico.

Las isotermas de adsorción fueron ajustadas utilizando los modelos de Freundlich y de Langmuir. Se determinaron las constantes de afinidad $\left(K_{F} y K_{L}\right)$, la intensidad de adsorción $(1 / n)$ y el recubrimiento superficial máximo $\left(\Gamma_{\max }\right)$. Los resultados muestran la dependencia con el pH de los parámetros de $K_{L}$ y $\Gamma_{\max }$ así como con la identidad de los horizontes y el tamaño de partícula.

Palabras clave: Glifosato, isoterma de adsorción, horizonte, perfil.

\section{Introduction}

In the last century the Province of Santiago del Estero, Argentina, lost more than $80 \%$ their natural forest as a result of irrational logging. In the arid soil of the province, agriculture replaced forests. Soybean cultivation was developed at the expense of others crops, native forests and livestock (Pérez-Carrera et al., 2008).

Pesticides are chemicals widely used in agriculture and their use increase with the increasing of crop areas. In particular, glyphosate (N-phosphonomethylglycine, $\mathrm{PMG}$ ) is used to remove annual grasses and perennial broadleaf weeds and woody species in agricultural, forestry and landscape. Thus, PMG is a non selective, post-emergent 
and broad-spectrum commercial herbicide used worldwide in soybean agriculture. In the soil, the main way of PMG degradation is microbial mediated, considering that abiotic mineralization of PMG for the horizon A exceeds $1 \%$ reaching a maximum of $12 \%$ degradation for 60 days exposure (Jacobsen et al., 2008).

PMG exhibits fast vertical mobility in soil, reaching high concentrations in deeper horizons where degradation is slower (Veiga et al., 2001).

PMG is a good chelating agent and can coordinate metal ion in aqueous solution, especially at near-neutral $\mathrm{pH}$ levels where carboxylate and phosphonate chemicals groups are deprotonated forming strong complexes (Barja et al., 2001). It can also be retained in the soil through adsorption onto aluminum and iron oxides (Nowack and Stone, 1999; Barja and dos-Santos-Afonso, 2005), clays (Damonte et al., 2007; Khoury et al., 2010 and references cited therein) and organic matter (Sposito, 1984; Piccolo et al., 1996).

The PMG adsorption on soils or clays was studied by several authors (Nomura and Hilton, 1977; McConnell and Hossner, 1985; Morillo et al., 2000; Sheals et al., 2002; Pessagno et al., 2008). In all the cases, adsorption decreased with a $\mathrm{pH}$ increase following an anionic adsorption behavior.

The study of competitive adsorption between PMG and phosphate on iron oxides had shown that PMG could be exchanged by phosphate (McBride and Kung, 1989; Gimsing and Borggaard, 2001), but the exchange on clays or soils is not so easy to characterize (Dion et al., 2001). When the initial phosphate level is high the glyphosate sorption decreases (Dion et al., 2001).

Thus, the surface coverage and the affinity constants for adsorption on iron oxides are higher than on clays minerals or soils, but the experimental results suggest that phosphonate is the liable chemical group for the surface coordination through inner-sphere surface complexes formation (dos-Santos-Afonso et al., 2004; Pessagno et al., 2005, 2008; Tévez et al., 2008). Previous studies on the surface coverage and the adsorption isotherms of this herbicide on soil fractions from different provinces of Argentina (Santa Cruz, Misiones, and Corrientes) followed similar patterns to those of the pure minerals that form these soils (Pessagno et al., 2005).

The aim of this work is to study the adsorption of PMG onto three different horizons of soils from Santiago del Estero Province, Argentina, with different mineral composition to understand how the mineral composition and $\mathrm{pH}$ are controlling the environmental fate of glyphosate.

\section{Materials and methods}

\subsection{Chemicals}

All chemicals utilized were of analytical reagent grade and were used without further purification. All solutions and soil dispersions were prepared using Milli-Q water.
PMG solutions were fresh and prepared daily by dissolving the herbicide in Milli-Q water. All PMG solution concentrations ranged from 0.05 to $10 \mathrm{mM}$.

\subsection{Study area}

The study area is located near Quimili in the center-east of Santiago del Estero Province between $62^{\circ} 06^{\prime} \mathrm{W}$ and $61^{\circ}$ $52^{\prime} \mathrm{W}$ and, $27^{\circ} 24^{\prime} \mathrm{S}$ and $28^{\circ} 00^{\prime} \mathrm{S}$ (Figure 1). Climate is semiarid mesothermal, with an average annual temperature of $19.6^{\circ} \mathrm{C}$ and rainfall of between 600 and $750 \mathrm{~mm}$ per year concentrated in the spring-summer period (TorresBruchman, 1981).

The sampling area is a soil catena corresponding to that found in recent agriculture (9 years) and low for ancient agriculture $(25-27$ years).

The soil is derived from loessic sediments and it is located at a depression relief, and classified as Typic Pachic Haplustoll with grasslands, Elionurus muticus (Lorenz et al., 2000).

Samples were taken up to $130 \mathrm{~cm}$ of depth (Figure 2.A) from three very well differenced horizons classified as Ap $(0-18 \mathrm{~cm}), \mathrm{AB}(18-50 \mathrm{~cm})$ and $\mathrm{BC}(105-130 \mathrm{~cm})$. The Ap is the uppermost mineral horizon, disturbed by plowing or other agricultural practices. $\mathrm{AB}$ and $\mathrm{BC}$ are transitional horizons, wherein the horizon properties are dominated by horizon A properties but also have characteristics of $\mathrm{B}$ horizon $(\mathrm{AB})$ or by horizon $\mathrm{B}$ properties but also have characteristics of $\mathrm{C}$ horizon (BC). The soil at depths between 50 and $105 \mathrm{~cm}$ has intermediate characteristics varying in a continuous from $\mathrm{AB}$ to $\mathrm{BC}$ and was not considered in this study. An schematic top view of pit trial is shown in Figure 2.B, each horizon was sampled at three different places indicated as 1,2 and 3, and afterward they were mixed to get one sample per horizon.

\subsection{Characterizations}

The fresh soil samples were air-dried and ground to pass a sieve of $2 \mathrm{~mm}$. $\mathrm{pH}$ was measured in $0.01 \mathrm{M} \mathrm{CaCl}_{2}$ solution at 1:2.5 ratio of soil suspension (Hendershot et al., 1993; Schlichting et al., 1995) using a combined glass electrode. Organic matter (OM) content and soils chemical analysis were determined by the dichromate oxidation method (Schlichting et al., 1995). The available phosphorus (P) is the inorganic $\mathrm{P}$, that is extractable at pH 8.5 and was determined following the experimental procedure described in Olsen et al., 1954 and Page et al., 1982. The total surface area ( $\mathrm{Sw}$ ) was measured by $\mathrm{H}_{2} \mathrm{O}$ adsorption (Torres-Sánchez and Falasca, 1997). The total iron oxides $\left(\mathrm{Fe}_{\text {tot }}\right)$ and amorphous iron oxides $\left(\mathrm{Fe}_{\text {amorph }}\right)$ were established by dithionite (Holmgren, 1967) and oxalate method (McKeague, 1967), respectively.

Soils samples were mixed with Lithium Metaborate/ Lithium Tetraborate $\left(\mathrm{LiBO}_{2} / \mathrm{Li}_{2} \mathrm{~B}_{4} \mathrm{O}_{7}\right)$ and fused in a furnace. The molten melt was completely dissolved in acidic 


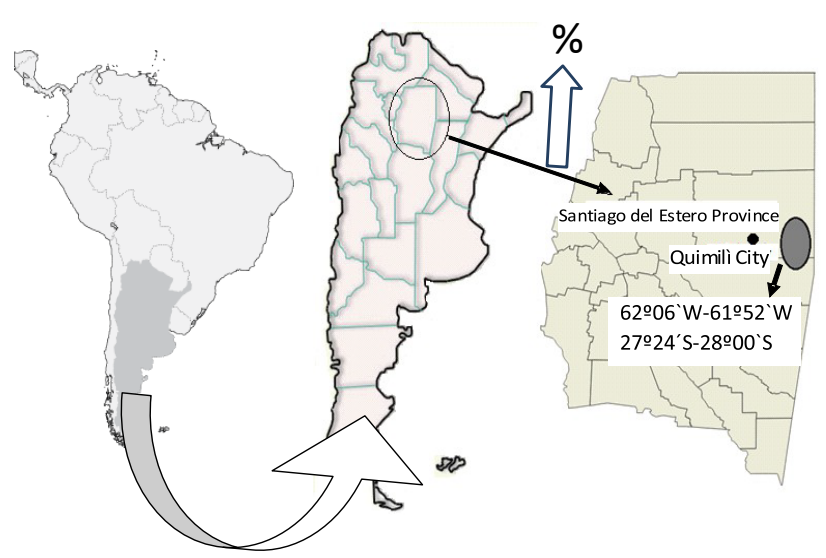

Figure 1. Map of South America, Argentina and Santiago del Estero Province. The sampling area near Quimili City is represented by 0 .

media of $5 \%$ nitric acid. This solution was analyzed for major and selected trace elements by Inductively Coupled Plasma - Atomic Emission Spectroscopy (ICP-AES) The sample composition are reported as oxide percentage.

The mineralogical composition and quantitative analysis of the soils were determined by X-ray Diffraction (XRD) and using the Rietveld method (Rietveld, 1969).

Point of zero net proton charge (PZNPC) or point zero salt effect (PZSE) is the $\mathrm{pH}$ where the net adsorption of protons and hydroxyl ions on the surfaces is independent of electrolyte concentration. Titration curves, when surface charge is plotted against $\mathrm{pH}$, frequently showed a common intersection point that match with PZNPC.

PZNPC was determined by potentiometric titration of soils dispersions starting from natural $\mathrm{pH}$ values near neutrality and by adding increasing amounts of standardized $\mathrm{NaOH}$ or $\mathrm{HCl} 0.1 \mathrm{M}$ at different initial ionic strength $(0.1,0.01$ and $0.0012 \mathrm{M} \mathrm{KCl})$ under $\mathrm{N}_{2}$ atmosphere. Soils dispersions were prepared using Milli- $\mathrm{Q}$ water free of $\mathrm{CO}_{2}$, and treated by continuous bubbling of $\mathrm{N}_{2}$, for at least one hour before starting the titrations. The extent of adsorbed $\mathrm{H}^{+}$ and $\mathrm{OH}^{-}$by soil material was determined by subtracting the quantity of $\mathrm{HCl}$ or $\mathrm{NaOH}$ required to bring the dispersion and the electrolyte solution without soil to the same $\mathrm{pH}$. The surface charge was calculated as follows:

$$
\mathrm{Q}=\left\{\equiv \mathrm{SOH}_{2}^{+}\right\}-\left\{\equiv \mathrm{SO}^{-}\right\}=\frac{\left(\mathrm{V}_{\text {tit }}-\mathrm{V}_{\mathrm{b}}\right)^{*}[\mathrm{tit}]}{\mathrm{m}}
$$

where $\mathrm{Q}, \mathrm{V}_{\mathrm{Tit}}, \mathrm{V}_{\mathrm{b}}$, [tit] and $\mathrm{m}$ are the surface charge, the volume of titrant used for dispersion titration, the volume of titrant used for electrolyte titration, titrant concentration and the mass of the solid, respectively.

\subsection{Adsorption experiment}

The adsorption of herbicide by the soils was studied using

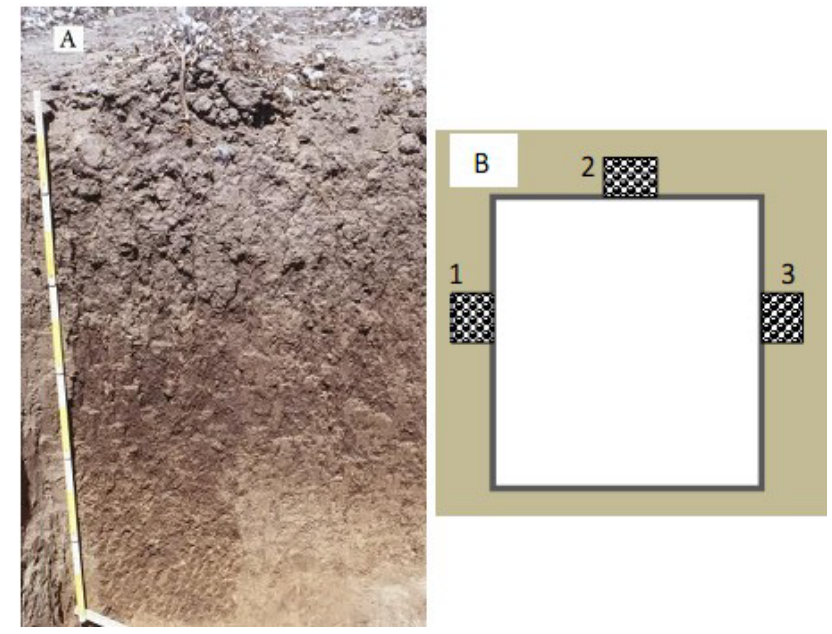

Figure 2. A: Pit profile from where samples were taken and B: schematic top view of trial pits and sampling site.

batch experiments. Solutions of different concentration of glyphosate in a final volume of $11 \mathrm{~mL}$ were added to 0.100 $\mathrm{g}$ of soil samples dispersions. Dispersions were kept in constant agitation overnight at constant $\mathrm{pH}$, ionic strength and room temperature to reach equilibrium. $\mathrm{pH}$ was adjusted during the experiment using small aliquots of $\mathrm{HCl}$ or $\mathrm{NaOH}$ solutions $(0.10 \mathrm{M})$ and ionic strength was kept constant $(0.1 \mathrm{M})$ using a $\mathrm{KNO}_{3}$ solution. The sample was filtered through a $0.45 \mu \mathrm{m}$ membrane and adsorbed glyphosate was calculated from the difference between the total added ligand and the supernatant concentration (Ce). PMG was evaluated by ion chromatography (Zhu et al., 1999) using a DIONEX DX-100 instrument with a conductivity detector, a sample injection valve, and a $25 \mu \mathrm{L}$ sample loop. Two plastic anion columns were coupled in series to serve both as precolumn (DIONEX AG-4) and analytical chromatographic column (DIONEX AS-4). The suppressor was regenerated with $50 \mathrm{mM} \mathrm{H}_{2} \mathrm{SO}_{4}$ with a flow rate of $12.5 \mathrm{~mL} \cdot \mathrm{min}^{-1}$. A mixture of $\mathrm{NaOH} / \mathrm{CO}_{3}^{-2} 4 \mathrm{mM} / 9 \mathrm{mM}$ was chosen as eluent with a flow rate of $1 \mathrm{~mL} \cdot \mathrm{min}^{-1}$. The typical experimental error is lower than $5 \%$ for all results.

\section{5. $\mathrm{pH}$ effect}

The $\mathrm{pH}$ dependence of the glyphosate uptake by soil horizons was investigated using batch isotherm experiments in a pH range from 2 to 8 with a soil concentration of 9.1 g.L${ }^{1}$ and different initial concentrations of PMG at a constant ionic strength of $0.1 \mathrm{M}$ of $\mathrm{KNO}_{3}$. The $\mathrm{pH}$ was measured using a Metrohm $644 \mathrm{pH}-$ meter with a combined glass microelectrode, and the $\mathrm{pH}$ was adjusted throughout the experiments using $0.1 \mathrm{M} \mathrm{HCl}$ or $0.1 \mathrm{M} \mathrm{NaOH}$. Adsorption experiments were conducted in triplicate following the procedure described above. There were no significant differences within each replicate $(p<0.01)$. The expressed values represent the average of the obtained results. 


\subsection{Isotherms Modeling}

The relationship between the ligand uptake and the sorbate equilibrium concentration at constant temperature is known as the adsorption isotherm. The adsorbent capacity of a certain material is related to the material balance adsorption: the sorbate that disappears from solution must be in the adsorbent. There are a considerable number of expressions that describe adsorption isotherms and between them, Freundlich and Langmuir models were chosen and applied for describing the equilibrium data.

\subsubsection{Freundlich Model}

The Freundlich isotherm fits many soil adsorption systems and is represented by equation (2):

$$
\Gamma_{\mathrm{e}}=\mathrm{K}_{\mathrm{F}} * \mathrm{C}_{\mathrm{eq}}^{1 / \mathrm{n}}
$$

where, $\Gamma_{\mathrm{e}}$ is adsorption per unit area of adsorbent; $\mathrm{K}_{\mathrm{F}}$ is the Freundlich constant indicating the relative adsorption capacity while $1 / \mathrm{n}$ is the index of the heterogeneity of the surface or the adsorption intensity and $\mathrm{C}_{\mathrm{eq}}$ is the equilibrium concentration of adsorbate in solution.

\subsubsection{Langmuir Model}

The Langmuir isotherm is a well known model that indicates a decrease of the available surface sites as the adsorbent concentration increases. The Langmuir isotherm assumes monolayer adsorption:

$$
\Gamma=\Gamma_{\max } \frac{K_{L} C_{e}}{1+K_{L} C_{e}}
$$

where $\Gamma$ is the amount of glyphosate adsorbed $\left(\mu \mathrm{mol} . \mathrm{m}^{-2}\right)$, $\Gamma_{\max }$ is the maximum amount of glyphosate adsorbed on the surface $\left(\mu \mathrm{mol} . \mathrm{m}^{-2}\right)$ at a fixed $\mathrm{pH}$ and temperature, $K_{L}$ is the Langmuir adsorption constant $\left(\mathrm{mM}^{-1}\right)$ which is related to the free energy of the reaction and $\mathrm{C}_{\mathrm{e}}$ is the equilibrium concentration of herbicide in the solution $(\mathrm{mM})$. In other words, $\Gamma_{\max }$ is the concentration of PMG surface saturation.

\section{Results and Discussion}

Soil characteristics, chemical analysis, mineralogical composition and quantitative analysis are presented in Table 1, 2 and 3 respectively. XRD of the three soil horizons are shown in Figure 3.

The experimental curves of PZNPC recorded for the $\mathrm{BC}$ horizon are illustrated in Figure 4. Similar behavior was found for all the horizons that showed PZNPC values in the range of $7.1-8.1$ (Table 1) following the sequence: $\mathrm{Ap}<\mathrm{AB}<\mathrm{BC}$. PZNPC value can be explained by the absence of clay minerals with a negative permanent charge, while the presence of 2:1 clays shift the PZNPC to lower $\mathrm{pH}$ values (Table 3 ).

The higher PZNPC value for the horizons corresponds to horizon $\mathrm{BC}$ that contains similar amount of quartz, lower amount of feldspars (andesine) and high amount of illite. PZNPC increase with andesine feldspar content and OM decrease. The determination coefficients of a linear fit were $\mathrm{R}_{\text {andesine }}^{2}=0.9971$ and $\mathrm{R}_{\text {OM }}^{2}=0.9189$. The analysis of the three parameters variations in a $3 \mathrm{D}$ plot presented a determination coefficient of $\mathrm{R}^{2}=1.0000$ and a constant variance test of $\mathrm{p}<0.0001$.

To describe the adsorption behavior Freundlich and Langmuir models were applied to the equilibrium data.

The PMG adsorption isotherms of soils dispersions equilibrated at different $\mathrm{pH}$ values are shown in Figure 5. The Freundlich model parameters values $\left(\mathrm{K}_{\mathrm{F}}\right.$ and $1 / \mathrm{n}$ ) were calculated using equation 2 and are given in Table 4 . The $1 / \mathrm{n}$ values vary between 0.1 and 1 , which indicates that this model could be used for interpreting the data. The correlation between experimental and calculated curves had a p-level between 0.137 and 0.0035 ; the determination

Table 1. Characteristics of agriculture soils profile from Santiago del Estero/Argentina.

\begin{tabular}{cccccccc}
\hline \multirow{2}{*}{ Horizon } & $\begin{array}{c}\mathrm{pH} \\
\left(\mathrm{CaCl}_{2} 1: 2.5\right)\end{array}$ & $\begin{array}{c}\mathrm{OM} \\
\left(\mathrm{g} \mathrm{C}^{\mathrm{K}} \mathrm{Kg}^{-1}\right)\end{array}$ & $\begin{array}{c}\mathrm{P} \\
\left(\mu \mathrm{g} \cdot \mathrm{g}^{-1}\right)\end{array}$ & $\begin{array}{c}\mathrm{Sw} \\
\left(\mathrm{m}^{2} \cdot \mathrm{g}^{-1}\right)\end{array}$ & $\begin{array}{c}\mathrm{Fe}_{\text {amorph }}\left(\mathrm{mg} \cdot \mathrm{g}^{-1}\right) \\
\left(\mathrm{mg} \cdot \mathrm{g}^{-1}\right)\end{array}$ & $\begin{array}{c}\mathrm{Fe}_{\text {tot }} \\
\mathrm{PZNPC}(\mathrm{pH})\end{array}$ \\
\hline $\mathrm{Ap}$ & 5.90 & 23.30 & 43.34 & 188 & 0.239 & 1.66 & 7.1 \\
$\mathrm{AB}$ & 5.75 & 17.10 & 6.67 & 259 & 0.158 & 1.91 & 7.4 \\
$\mathrm{BC}$ & 6.02 & 12.10 & 1.19 & 242 & 0.095 & 0.99 & 8.1 \\
\hline
\end{tabular}

Table 2. Chemical Analysis of agriculture soils profile from Santiago del Estero, Argentina.

\begin{tabular}{cccccccc}
\hline \multirow{2}{*}{ Horizon } & \multicolumn{7}{c}{ Chemical Analysis (\%) } \\
& $\mathrm{SiO}_{2}$ & $\mathrm{Al}_{2} \mathrm{O}_{3}$ & $\mathrm{Fe}_{2} \mathrm{O}_{3}$ & $\mathrm{CaO}$ & $\mathrm{MgO}$ & $\mathrm{Na}_{2} \mathrm{O}$ & $\mathrm{K}_{2} \mathrm{O}$ \\
\hline $\mathrm{Ap}$ & 64.6 & 12.25 & 3.51 & 1.47 & 1.14 & 1.70 & 2.43 \\
$\mathrm{AB}$ & 63.0 & 13.65 & 4.10 & 1.34 & 1.40 & 1.50 & 2.53 \\
$\mathrm{BC}$ & 63.0 & 14.05 & 4.42 & 1.44 & 1.62 & 1.56 & 2.66 \\
\hline
\end{tabular}


coefficients were between 0.7578 and 0.9953 for different $\mathrm{pHs}$ and horizons.

The Langmuir model was also applied to make an interpretation of $\mathrm{PMG}$ adsorption isotherms on soils dispersions equilibrated at different $\mathrm{pH}$ values. This is shown in Figure 5, where solid lines are calculated using this model (equation 3) and $\Gamma_{\max }$ and $K_{L}$, are given. The isotherm model parameters were obtained by a non-linear optimization using the Solver-Excel tool. The parameters values were obtained from the plot of the inverse of the surface coverage as a function of the inverse of the equilibrium concentration. Results of the adsorption and surface coverage calculations were normalized with $\mathrm{Sw}$ data and the various horizons were contrasted. The correlation between experimental and calculated curves had a p-level between 0.050 and 0.001 ; the determination coefficients $\left(\mathrm{R}^{2}\right)$ obtained were between 0.9300 and 0.9999 ; and were higher than those obtained using the Freundlich model. Thus, the

Table 3. Mineralogical Composition of agriculture soils profile from Santiago del Estero, Argentina. Values in parenthesis represent estimated standard deviations.

\begin{tabular}{ccccccc}
\hline \multicolumn{6}{c}{ Mineralogical Composition (\%) } \\
Horizon & Quartz & Sanidine & Andesine & Illite & Magnetite \\
& & Feldspar & Feldspar & & \\
\hline Ap & $45.2(0.4)$ & $9.6(0.9)$ & $24.7(0.8)$ & $18.6(1.4)$ & $1.3(0.2)$ \\
AB & $39.8(0.5)$ & $9.6(0.8)$ & $23.5(0.7)$ & $25.9(1.5)$ & $1.2(0.3)$ \\
BC & $46.2(0.4)$ & $9.3(0.9)$ & $19.9(0.9)$ & $24.7(1.3)$ & $1.2(0.3)$ \\
\hline
\end{tabular}

Langmuir model would better represent the adsorption process of PMG on the Santiago del Estero Province soil.

The dependence of the surface coverage with PMG concentration in the various horizons at constant $\mathrm{pH}=5$ is shown in Figure 6. Horizon $\Gamma_{\max }$ sequence is $\mathrm{Ap}<\mathrm{AB}<\mathrm{BC}$. This behavior is similar to those found for PZNPC.

The dependence of the surface coverage with $\mathrm{pH}$ in the various horizons is also shown in Figure 5. The adsorption capacity increases from $\mathrm{pH} 8$ to 2 . This $\mathrm{pH}$ effect was normally observed during the adsorption of anionic species. Consequently, PMG interaction with the surface occurs throughout the anionic chemical groups (carboxylate or phosphonate) and not through the amine group ( $\mathrm{pKa}=$ 10.14) that is positively charged at the studied $\mathrm{pH}$ range (Figure 7).

The surface coverage decrease, $\Delta \Gamma_{\max }$, for horizon Ap is around $41 \%$ for this $\mathrm{pHs}$ range (Table 5). This difference is lower for horizons $\mathrm{BC}, 27 \%$, and $\mathrm{AB}, 12 \%$.

The different composition and properties of the soils (Table 1), will affect sorption of the sorbate. This variability may also be linked to the organic matter content (Table 1) because of the chemical groups present on the OM (carboxyl, hydroxyl, amine, phenoxy, etc) that can coordinate the solid inorganic surface active sites or block the access of PMG to the inorganic surface. In consequence, OM presence can reduce PMG adsorbed on the solid surface. In fact, $\Gamma_{\max }$ varies linearly with OM content with determination coefficients among $\mathrm{R}_{\mathrm{pH}=2}^{2}=0.9548$ and $\mathrm{R}_{\mathrm{pH}=8}^{2}=1.0000$. The affinities of the substances involved in the adsorption process are dependent on the identity and

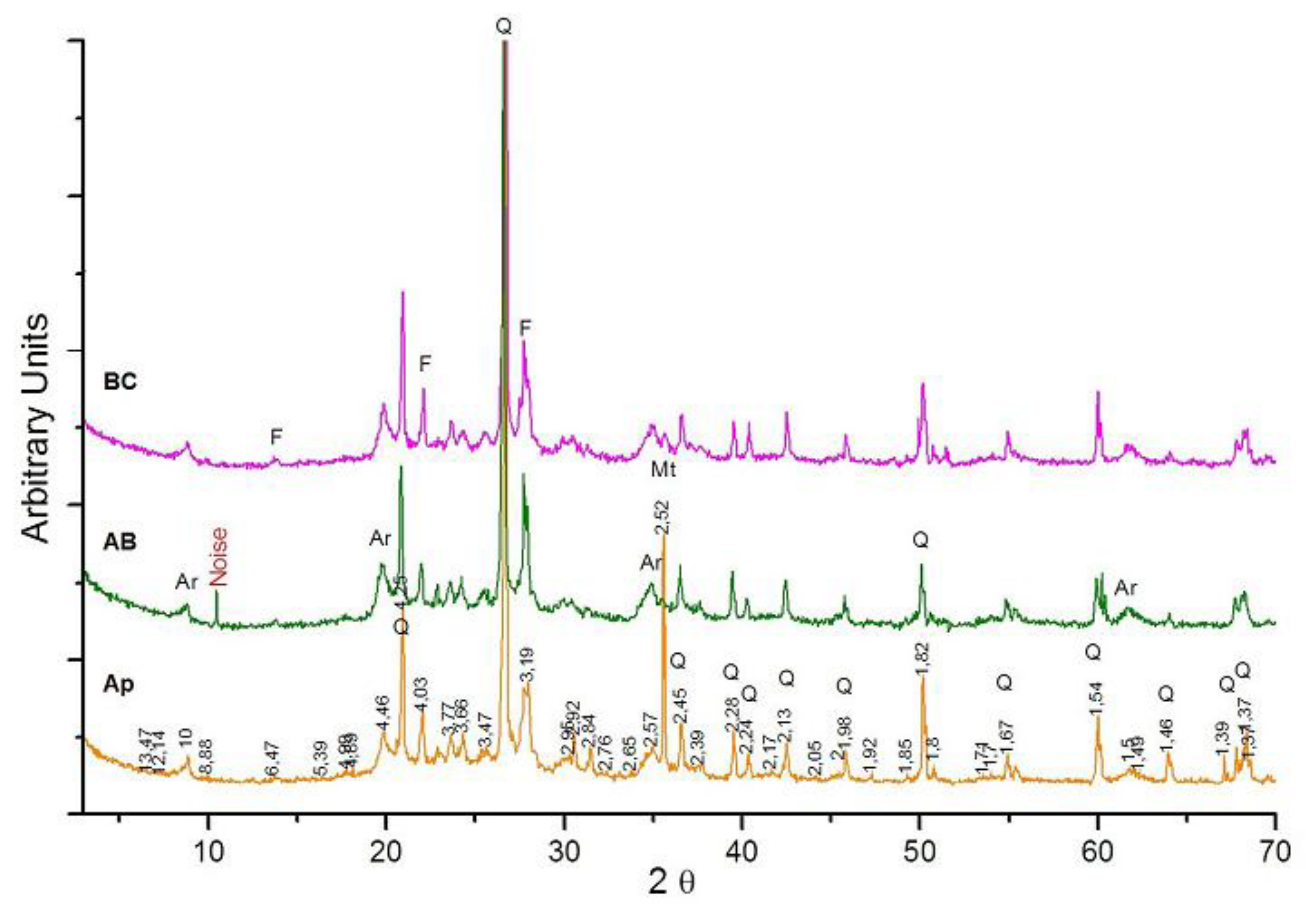

Figure 3. XRD of the three soil horizons. Q: Quartz, Ar: Clay, F: Feldspar, Mt: Magnetite. 


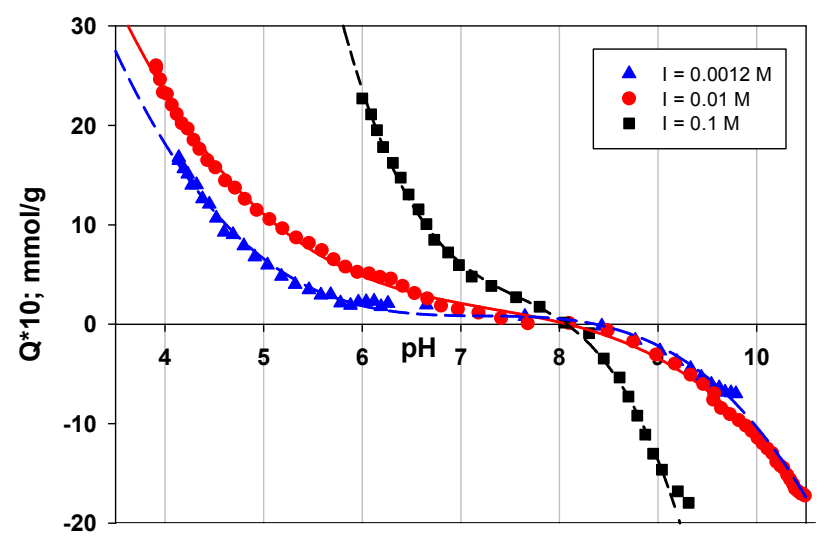

Figure 4. Potentiometric titration curves of the dispersions of the $\mathrm{BC}$ horizon at three ionic strengths $\left(I=1 / 2 \Sigma_{i} c_{i} z_{i}^{2}\right)$.

Table 4. Freundlich parameters (In $\left.\mu \mathrm{mol}^{1-1 / n} \cdot \mathrm{m}^{-2}\right)$ for glyphosate adsorption on Santiago del Estero Province soils.

\begin{tabular}{cccccccccc}
\hline $\begin{array}{c}\text { Horizon } \\
\mathbf{p H}\end{array}$ & $\mathbf{K}_{\mathbf{F}}{ }^{*} \mathbf{1 0} \mathbf{3}^{\mathbf{3}}$ & $\mathbf{1} \mathbf{\mathbf { n }}$ & $\mathbf{R}^{\mathbf{2}}$ & $\mathbf{K}_{\mathbf{F}}{ }^{*} \mathbf{1 0}^{\mathbf{3}}$ & $\mathbf{1} / \mathbf{n}$ & $\mathbf{R}^{\mathbf{2}}$ & $\mathbf{K}_{\mathbf{F}}^{*} \mathbf{1 0}^{\mathbf{3}}$ & $\mathbf{1} \mathbf{\mathbf { n }}$ & $\mathbf{R}^{\mathbf{2}}$ \\
\hline 2 & 7.3 & 0.46 & 0.9449 & 19.7 & 0.44 & 0.9745 & 5.3 & 0.64 & 0.9842 \\
3 & 6.7 & 0.47 & 0.9953 & 18.4 & 0.45 & 0.9894 & 4.9 & 0.65 & 0.9759 \\
4 & 5.9 & 0.47 & 0.9646 & 16.2 & 0.46 & 0.9654 & 4.7 & 0.63 & 0.9852 \\
5 & 5.6 & 0.46 & 0.9729 & 16.2 & 0.45 & 0.9652 & 4.6 & 0.63 & 0.9892 \\
6 & 5.0 & 0.48 & 0.7578 & 15.1 & 0.46 & 0.9862 & 4.3 & 0.62 & 0.9812 \\
8 & 3.8 & 0.47 & 0.9453 & 14.3 & 0.45 & 0.9749 & 3.0 & 0.64 & 0.9893 \\
\hline
\end{tabular}

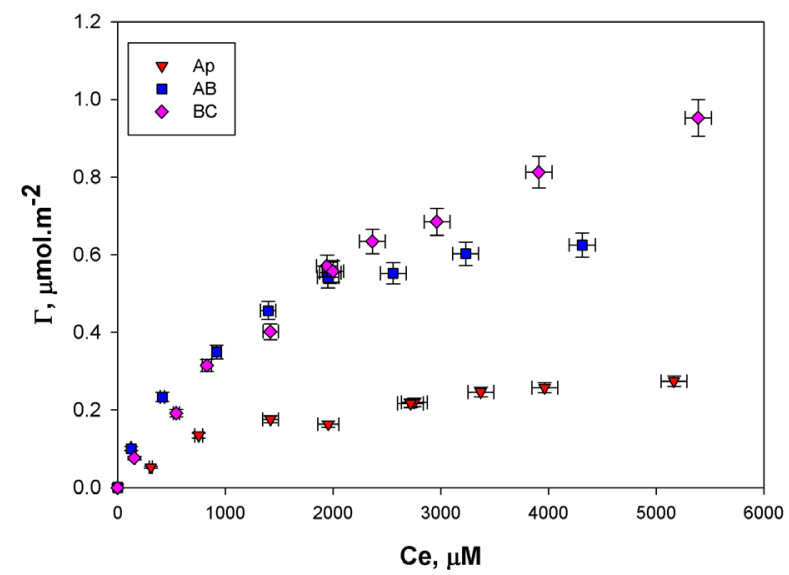

Figure 6. Adsorption isotherm of $\mathrm{PMG}$ on horizon $\mathrm{Ap}, \mathrm{AB}$ and $\mathrm{BC}$ at $\mathrm{pH} 5$.
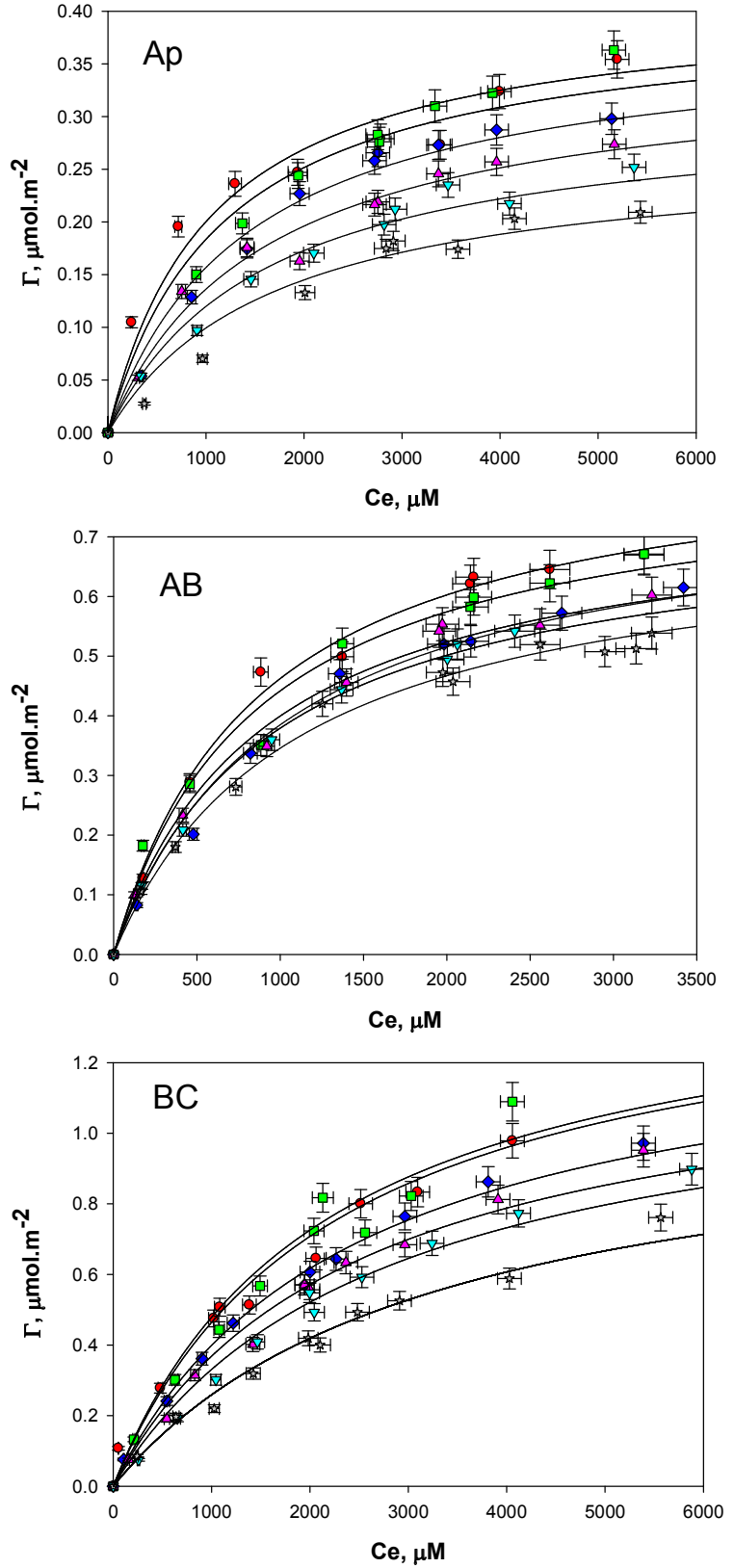

Figure 5. Adsorption isotherm of PMG on horizon Ap, AB and BC. Solid lines are calculated using Langmuir model with constants and maximum

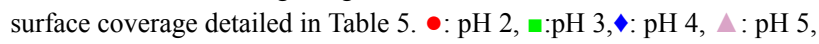
$\nabla: \mathrm{pH} 6$ and $\star: \mathrm{pH} 8$.

Table 5. Langmuir parameters for PMG adsorption on soils of Santiago del Estero Province, Argentina

\begin{tabular}{|c|c|c|c|c|c|c|c|c|c|}
\hline \multirow{2}{*}{$\begin{array}{c}\text { Horizon } \\
\text { pH }\end{array}$} & \multicolumn{3}{|c|}{ Ap } & \multicolumn{3}{|c|}{$A B$} & \multicolumn{3}{|c|}{ BC } \\
\hline & $\Gamma_{\max ,}{ }^{-2}$ & $\begin{array}{c}K_{L,} \\
\text { L.mmol }^{-1}\end{array}$ & $\mathbf{R}^{2}$ & $\Gamma_{\max ,}{ }^{-2}$ & $\begin{array}{c}\quad K_{L,} \\
\text { L.mmol }^{-1}\end{array}$ & $\mathbf{R}^{2}$ & $\begin{array}{c}\Gamma_{\max }, \\
\mu \text { mol.m }^{-2}\end{array}$ & $\begin{array}{c}K_{L,} \\
\text { L.mmol }^{-1}\end{array}$ & $\mathbf{R}^{2}$ \\
\hline 2 & 0.41 & 0.91 & 0.9572 & 0.81 & 0.93 & 0.9936 & 1.50 & 0.40 & 0.9331 \\
\hline 3 & 0.40 & 0.87 & 0.9723 & 0.82 & 0.93 & 0.9833 & 1.49 & 0.42 & 0.9664 \\
\hline 4 & 0.38 & 0.73 & 0.9874 & 0.78 & 0.92 & 0.9925 & 1.36 & 0.41 & 0.9955 \\
\hline 5 & 0.34 & 0.67 & 0.9769 & 0.76 & 0.92 & 0.9932 & 1.27 & 0.40 & 0.9854 \\
\hline 6 & 0.31 & 0.63 & 0.9633 & 0.74 & 0.91 & 0.9974 & 1.23 & 0.39 & 0.9858 \\
\hline 8 & 0.24 & 0.61 & 0.9424 & 0.72 & 0.90 & 0.9926 & 1.10 & 0.28 & 0.9830 \\
\hline
\end{tabular}




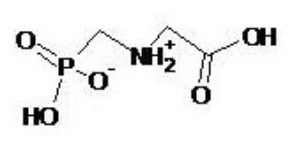

I

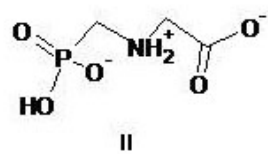

II
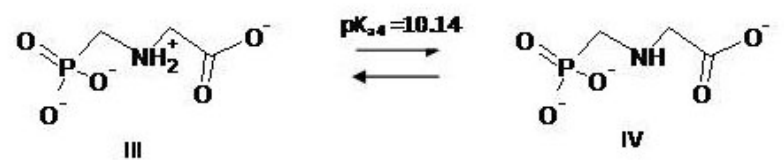

Figure 7. PMG acid-base equilibrium.

number of chemical groups present on the OM.

The highest adsorption capacity is obtained by horizon $\mathrm{BC}$ followed by horizon $\mathrm{AB}$, and the lowest for horizon Ap. A similar sequence was obtained for PZNPC (Table 1), indicating that the horizon with higher positive surface charge presents higher PMG surface coverage.

The ratio of the $\Gamma_{\max }$ of the horizons $\left(\mathrm{R}_{\mathrm{H} 1 / \mathrm{H} 2}\right)$ was calculated as follow

$$
\mathrm{R}_{\mathrm{H} 1 \mathrm{H} 2}=\frac{\Gamma_{\operatorname{maxH} 1}}{\Gamma_{\max 2}} * 100
$$

where $\mathrm{H} 1$ and $\mathrm{H} 2$ denote two different horizons, $\Gamma_{\operatorname{maxH} 1}$ and $\Gamma_{\operatorname{maxH} 2}$ indicate the maximum coverage of $\mathrm{H} 1$ and $\mathrm{H} 2$ horizons, respectively. This ratio between the horizons $\mathrm{BC}$ and $A B$ was $R_{B C / A B}=46 \%$, between horizons $B C$ and $A p$ was $R_{\mathrm{BC} / \mathrm{Ap}}=72 \%$ and between horizon $\mathrm{AB}$ and $\mathrm{Ap}$ was $\mathrm{R}_{\mathrm{AB} /}$ ${ }_{\mathrm{Ap}}=50 \%$. These percentages are opposed to the phosphate content that follows the order of $\mathrm{Ap}>\mathrm{AB}>\mathrm{BC}$. The high adsorption on deep horizons with regard to horizon Ap could be due to the competition of herbicide with phosphate groups for surface sites (Dion et al., 2001; Gimsing et al., 2007). Adsorption of glyphosate and phosphate in soil is similar to that which occurs on clay minerals (Dion et al., 2001; Gimsing and dos-Santos-Afonso, 2005).

The highest adsorption constants correspond to horizon $\mathrm{AB}$ (Table 5). The changes in the adsorption affinity between horizon $\mathrm{BC}$ and $\mathrm{AB}$ reach $\Delta K_{L}=46 \%$ while horizon $\mathrm{BC}$ decreases $73 \%$ in respect to horizon Ap.

The relatively high phosphate and low surface area (Table 1) of the Ap horizon, could be the cause for which it reaches its maximum at relatively low concentrations of PMG adsorption. The greater slope of the adsorption curves in the $\mathrm{AB}$ horizon indicate that $\mathrm{PMG}$ binds more strongly to the active sites of this horizon. Previous studies indicated that PMG bound iron oxides surfaces more strongly than clay minerals (dos-Santos-Afonso et al., 2004). Thus, the active site of PMG adsorption on the AB horizon could be the surface iron atoms and the higher adsorption in this horizon is directly related to higher iron content.

The adsorption on horizon $\mathrm{BC}$ does not reach maximum coverage in the experimental conditions. The adsorption isotherms with a low initial slope describe an adsorption process with characteristic adsorption constants of low energy interaction (Figure 5).

Note that in the working $\mathrm{pH}$ range an acid-base dissociation of the PMG molecule that contains amine, carboxylate, and phosphonate functional groups take place The constant and the equilibrium reactions of acid-base dissociation of glyphosate (Barja and dos-Santos-Afonso, 1998) are shown in Figure 7, where I, II and III are the main species presents in the studied $\mathrm{pH}$ range. Previous studies suggested that the adsorption process occurs by surface complex formation via phosphonate group coordination to the mineral surface (Barja and dos-Santos-Afonso, 2005; Khoury et al., 2010). Similar behavior should be expected for the adsorption of PMG on soils where coordination would occur on the surface of the minerals that compose them.

\section{Conclusions}

The major factor in PMG adsorption on soil samples is given by the $\mathrm{pH}$, which could be due to the influence of this parameter on the PMG molecule and on the surface charge of the soil particles. PMG adsorption increase with acidity, and this increase correspond to the adsorption of a ligand with a negative net charge.

Sorption of glyphosate in soils is similar to the adsorption of the organic molecule on the soil components such as clay minerals, iron oxides and OM. For these soils with a low organic matter contents and/or similar amounts of clay in the various horizons, the adsorption would be determined by the content of phosphorus, iron oxide and the specific surface. Regarding the relative adsorption capacity of the soil, the adsorption process has a different behavior profile, where the deeper horizon (BC) has a higher capacity retention for this herbicide. The lower adsorption in the $\mathrm{AB}$ and Ap horizons could be influenced by the higher content of phosphorus. However, the strength of the interaction, as given by the Langmuir Model Constant $\mathrm{K}_{\mathrm{L}}$ is larger on horizon $\mathrm{AB}$ and would be linked to the illite and iron oxide content that have a better distribution in $\mathrm{AB}$.

It should be noted that the Langmuir adsorption model is the best fit to the adsorption experimental results in these soils, although the Freundlich model has a good fit for some $\mathrm{pHs}$.

Given the adsorption extent found in this study, it is expected that pesticides will be retained in these soils. This strong interaction could prevent the pesticides movement into the groundwater. On the other hand, this retention rate could result in the release of the herbicide on the 
environment due to displacement by runoff.

\section{Acknowledgements}

The authors acknowledge the Universidad de Buenos Aires, Secretaría de Ciencia y Técnica and MINCyTANPCyT- FONCyT for financial support. The authors are also grateful to Susana Conconi and Jorge Maggi from Centro de Tecnología de Recursos Minerales y Cerámica (CETMIC) for Rietveld analysis of soils.

\section{References}

Barja, B., dos-Santos-Afonso, M., 1998, An ATR-FTIR study of glyphosate and its $\mathrm{Fe}(\mathrm{III})$ complex in aqueous solution: Environmental Science and Technology, 32, 3331-3335.

Barja, B., dos-Santos-Afonso, M., 2005, Aminomethylphosphonic acid and Glyphosate adsorption onto goethite: a comparative study: Environmental Science and Technology, 39, 585-592.

Barja, B., Herszaje, J., dos-Santos-Afonso, M., 2001, Iron (III)phosphonate complexes: Polyhedron, 20, 1821-1830.

Damonte, M., Torres-Sánchez, R., dos-Santos-Afonso, M., 2007, Some aspects of the glyphosate adsorption on montmorillonite and its calcined form: Applied Clay Science, 1-3(36), 86-94.

Dion, H., Harsh, J., Hill Jr., H., 2001, Competitive sorption between glyphosate and inorganic phosphate on clay minerals and low organic matter soils: Journal of Radioanalytical and Nuclear Chemistry, 249(2), 385-390.

dos-Santos-Afonso, M., Barja, B., Pessagno, R., Tevez, H., 2004, Glyphosate adsorption on soils, in Division of Environmental Chemistry, New York, USA.: American Chemical Society.

Gimsing, A., Borggaard, O., 2001, Effect of $\mathrm{KCl}$ and $\mathrm{CaCl}_{2}$ as background electrolytes on the competitive adsorption of glyphosate and phosphate on goethite, Clays Clay Minerals, 49, 270-275.

Gimsing, A., dos-Santos-Afonso, M., 2005, Glyphosate, in Nowack, B., VanBriesen, J. (ed.), Biogeochemistry of Chelating Agents: ACS Symposium Series, USA, 910, 263-277.

Gimsing, A., Szilas, C., Borggaard, O., 2007, Sorption of glyphosate and phosphate by variable-charge tropical soils from Tanzania, Geoderma, 138, 127-132.

Hendershot W.H., Lalande, H., Duquette, M., 1993, Soil reaction and exchangeable acidity: In Carter M.R. (ed), Soil sampling and methods of analysis: Lewis Publishers, Boca Raton, 141-145.

Holmgren, G., 1967, A rapid citrate-dithionite extractable iron procedure: Soil Science Society of America Journal, 31, 210-211.

Jacobsen, C.S., van der Keur, P., Ivensen, B.V., Rosenberg, P., Barlebo, H.C., Torp, S., Vosgerau, H., Juhler, R.K., Ernstsen, V., Rasmussen, J., Brinch, U.C., Jac, O.H., 2008, Variation of MCPA, metribuzine, methyltriazine-amine and glyphosate degradation, sorption, mineralization and leaching in different soil horizons: Environmental Pollution, 3(156), 794-802.

Khoury, G., Gehris, T., Tribe, L., Torres-Sánchez, R.M., dos-SantosAfonso, M., 2010; Glyphosate adsorption on montmorillonite: An experimental and theoretical study of surface complexes: Applied Clay Science, 2(50), 167-175.

Lorenz, G., Bonelli, C., Roldán, S., Araya, C., 2000, Soil quality changes due to land use in a Kastanozem-Phaeozemsoilscape of semiarid Chaco: Mitteilungen der Deutschen Bodenkundlichen Gesellschaft, 92, 169-172.

McKeague, J.A., 1967, An evaluation of $0.1 \mathrm{M}$ pyrophosphate and pyrophosphate-dithionite in comparison with oxalate as extractants of the accumulation products in podzols and some other soils:
Canandian Journal of Soil Science, 47, 2, 95-99.

McBride, M., Kung, K., 1989, Complexation of glyphosate and related ligands with iron (III): Soil Science Society of America Journal, $53,1668-1673$.

McConnell, J., Hossner, L., 1985, pH-dependent adsorption isotherms of glyphosate: Journal of Agricultural Food Chemistry, 33, 1075-1078

Morillo, E., Undabeytia, T., Maqueda, C., Ramos, A., 2000, Glyphosate adsorption on soils of different characteristics. Influence of copper addition: Chemosphere, 40, 103-107.

Nomura, N., Hilton, H., 1977, The adsorption and degradation of glyphosate in five. Hawaiian sugarcane soils: Weed Research, 17, 113-121.

Nowack, B., Stone, A., 1999, Adsorption of phosphonates onto the goethitewater interface: Journal of Colloid Interface Science, 214, 23-30.

Olsen, S., Cole, C., Watanabe, F., Dean, L., 1954, Estimation of available phosphorous in soils by extraction with sodium bicarbonate, United States of America, Department of Agriculture.

Page, A., Miller, R., Keeney, D., 1982, Part 2: Chemical and microbiological properties, in Methods of soil analysis, Madison, Wisconsin, USA.

Pérez-Carrera, A., Moscuzza, C., Fernández-Cirelli, A., 2008, Efectos socioeconómicos y ambientales de la expansión agropecuaria. Estudio de caso: Santiago del Estero, Argentina. Ecosistemas 17(1), 5-15.

Pessagno, R., dos-Santos-Afonso, M., Torres-Sánchez, R., 2005, $\mathrm{N}$-(phosphonomethyl)glycine interactions with soil: The Journal of Argentine Chemical Society. Anales de la Asociación Química Argentina, 4-6(93), 97-108.

Pessagno, R., Torres-Sánchez, R., dos-Santos-Afonso, M., 2008, Glyphosate behavior at soil and mineral-water interfaces: Environmental Pollution, 153, 53-59.

Piccolo, A., Celano, G., Conte, P., 1996, Adsorption of glyphosate by humic substances: Journal of Agricultural and Food Chemistry, $44,2442-2446$.

Rietveld, H.M., 1969, A profile refinement method for nuclear and magnetic structures: Journal Applied Crystallography, 2, 65-71.

Schlichting, E., Blume, H., Stahr, K., 1995, Soils Practical, WissenschaftsVerlag Blackwell, Berlin, Germany, 295 p.

Sheals, J., Sjöberg, S., Persson, P., 2002, Adsorption of glyphosate on goethite: molecular characterization of surface complexes: Environmental Science and Technology, 36, 3090-3095.

Sposito, G., 1984, The surface chemistry of soils: Oxford University Press, New York, $234 \mathrm{p}$.

Tévez, H., dos-Santos-Afonso, M., Alvarez-Escalada, F.C., Serrano, M., Ruiz-Mostacero, N., 2008, Glifosato en fracciones de suelo de la provincia de Santiago del Estero, in V Congreso Iberoamericano de Física y Química Ambiental, Mar del Plata, Buenos. Aires, Argentina.

Torres-Bruchman, E., 1981, Climatología general y agrícola de la Provincia de Santiago del Estero, Ed. Universidad Nacional de Tucumán.

Torres-Sánchez, R., Falasca, S., 1997, Specific surface area and surface charges of some argentinian soils: Zeitschrift für Pflanzenernährung und Bodenkunde, 160, 223-226.

Veiga, F., Zapata, J., Marcos, M., Alvarez, E., 2001, Dynamics of glyphosate and aminomethylphosphonic acid in a forest soil in Galicia, north-west Spain: Science of the Total Environment, 271, 135-144.

Zhu, Y., Zhang, F., Tong, C., Liu., W., 1999, Determination of glyphosate by ion chromatography: Journal of Chromatography, 850, 297-301.

Manuscript received: October 27, 2014

Corrected manuscript received: February 7, 2015

Manuscript accepted: February 10, 2015 